\title{
Societies Without Borders
}

Volume 4 | Issue 2

Article 3

2009

\section{Under a Global Mask: Family Narratives and Local Memory in a Global Social Movement in Japan}

Nomiya

Follow this and additional works at: https://scholarlycommons.law.case.edu/swb

Part of the Human Rights Law Commons, and the Social and Behavioral Sciences Commons

\section{Recommended Citation}

Nomiya. 2010. "Under a Global Mask: Family Narratives and Local Memory in a Global Social Movement in Japan." Societies Without Borders 4 (2): 117-140.

Available at: https://scholarlycommons.law.case.edu/swb/vol4/iss2/3 


\title{
Under a Global Mask: Family Narratives and Local Memory in a Global Social Movement in Japan ${ }^{1}$
}

\author{
Daishiro Nomiya \\ Sophia University, Japan
}

\begin{abstract}
The present paper examines motivational aspects of the global peace movement, using as a case the World Peace Now movement in Japan. This campaign, which has extensive international networks and synchronized actions with global "waves of protest", is part of a global anti-war protest movement. Using data collected from interviews and a protest survey to gauge participation motives and attributed meanings to the participation, the paper argues that the campaign, despite its global outlook, is localized and historically idiosyncratic. Indifferent to the global, participants' motives are drawn from personal experiences and family narratives, and localized collective memory of the past. The paper offers "surface interaction" as concept to understand current global social movements among movement organizations in different countries.
\end{abstract}

\section{Keywords}

global social movements, motives, narrative, collective memory

In recent years, Sociologists, Political Scientists, and Globalization scholars have discussed the nature of global activism. One enduring source of discussion in this regard relates to the degree of coherence of recent global social movements. Just how coherent are global social movements, and how globally integrated are they?

The question looms large as skeptics question the extent of global-ness with increasing regularity. Observers find ideologically discrete possibilities in the future orientation of global social movements. This is true not

1) This research was funded by the Japan Economic Research Foundation and Japan Society for the Promotion of Science Grant-in-Aid for Scientific Research (B) (20330109). I am grateful to Doug McAdam for his encouragement and thoughtful comments on earlier drafts of the manuscript. Please direct all the correspondence to: d-nomiya@sophia.ac.jp. 
only of their ideological differences and inconsistencies, but also in their approach to conciliatory politics and in strategies. ${ }^{2}$

Despite such skepticism, many studies continue to emphasize the relevance of the global nature of social movements. As in the case of Zapatista struggle, ${ }^{3}$ many observe growing global connections across movement organizations residing in different parts of the world and increasing crossnational transmission of their messages. In fact, scholarly characterizations of global social movements remain diverse, so diverse as to have some researchers wonder whether today's global movements are "a confluence of movements," or "a collection of separate movements." 4

The existing literature on the integration and coherence of global social movements focuses on the structural factors that sustain global activism. Current research increasingly focuses on network building and the technologies that mediate movement organizations and collectivities. As a result, discussions on transnational communication across movement bodies and the emergence of overarching transnational civil organizations have proliferated. ${ }^{5}$ In contrast with the proliferation of a body of literature on the global structural merger of movements, comparatively little research investigates psychological and motivational aspects of global social movements. Certainly, there has been research to investigate ideology and thoughts of particular activist leaders of global movements and diffusion mechanisms of ideas. ${ }^{6}$ However, only a few research efforts have been made to date to investigate the global mentality of general participants constituting the majority of a global social action. Any effort to go beyond the realm of the particular individual becomes a challenge. An assessment of the mental dispositions of general participants in a global movement will have to embrace personal accounts and the movement sources from which the individuals are drawing. Personal accounts to highlight the meaning attribution of their action; Sources, even to a limited extent, to reconcile with existing categories of dispositions.

To cope with this difficulty, this paper uses multiple datasets that cover both individual and collective-level data, and attempts to grasp the moti-

2) Buttel 2003; Buttel and Gould 2004.

3) Cleaver 1998.

4) Brecher, Costello, and Smith 2000:15.

5) See, for instance della Porta et al. 2006; Diani and McAdam 2003; Moghadam 2000; Rucht 1999; Smith 1997.

6) For instance, McAdam and Rucht 1993; McDonald 2006; Olesen 2005. 
vational aspects of the participants in the global movement action, and examines the extent of the global mentality residing in it.

\section{Convergence and Divergence in the Global Mentality}

Scholarly observation investigating participants' frame of mind in global activism is divided into two major views. Some globalization theorists hold the idea that global activities, to a varying degree, merge into one large entity, embracing an increasing degree of coherence by way of a sense of the connectedness and shared awareness across movement activists in different parts of the world. Among theorists under this thesis is Albrow, who observes a new set of human mentalities in social movements in the era of globalization. ${ }^{7}$ According to him, an increasing commitment to the global values and concomitant mobilization of those sharing the same thoughts become the norm in the global age. Claiming that "globality" is the underlying force in the unfolding of the phenomenon called globalization, Albrow finds in global social movements motivations and ideas unprecedented by their predecessors. Such motivations include a sense of human responsibility toward the world as a whole, and of the common fate of humankind.

An ideological characterization of global social movements, such as Albrow's, redefines individual motivation of the participants in global collective action. Spybey, for example, contends that a defining characteristic of global social movements is the individualization of global issues. ${ }^{8}$ Global social movements differ from New Social Movements in that they tactically employ an appeal to the individuals who also share a sense of responsibility toward the future of the globe. Individuals in global social movements form their identities around a sense of the collective fate of humankind as a whole. Similarly, Hegedus argues that as we shift from the movements of the seventies to those of the eighties, we shift our attention to the planetary issues as well. ${ }^{9}$ This change in our attention alters the ethic of the individual in a direction toward what he calls "a new ethic of responsibility." Individuals are "globalized" through an increasing concern toward planetary problems.

As abstract as it sounds, their conceptualization is not without empirical foundations. A source of these ideas is the presence of and an increased

\footnotetext{
7) Albrow 1996.

8) Spybey 1996.

9) Hegedus 1989.
} 
sensibility to the problems of a global magnitude. Environmental pollution and climate change is one such example. Since many of these problems have an effect that transcends national boundaries, they require transnationally coordinated action with shared understanding on the causes and solutions to them. Also prominent in the last decade is a heightened sensibility to the problem of global inequality and poverty both at the domestic and international level. The so-called anti-globalization movement is a prime example. Many civil society organizations and groups attribute ongoing inequality to a global expansion of capitalism. Many of these groups argue that as exploitation expands to developing countries under the capitalist praxis and neoliberal ideology, so too does the widespread and deepening problem of poverty and inequality. ${ }^{10}$ Growing awareness to the problems of a global magnitude provides a platform on which various social movement organizations build shared understanding, cooperative action and a sense of collective identity. ${ }^{11}$ This convergence may reverberate to the individual level. Heightened awareness to global problems has led to recognition of the common fate of human kind. An effort to estimate their possible impact and to seek solutions in turn gears up an extended dialogue among movement activists, and eventually leads to an increased chance for shared interpretations and cooperative action.

Another intellectual source comprising the idea of global convergence of social movement mentality is an increase in cultural interaction and value dissemination. With modern communication technology, local ideas, thoughts, and ideologies instantly find audience on an international platform. Often these ideas and ideologies are employed in new local contexts, whereby they are readopted to create a new cultural signification. ${ }^{12}$ Studies on the Zapatista movement provide ample illustrations of cross-cultural transmission and delocalization of endogenous ideas and cultural traits. ${ }^{13}$

Taken all together, the above arguments suggest that current transnational social movements are increasingly merging. Transnational communication networks, a shared understanding of planetary problems, and the nourishment of common interpretations and solutions all point to an emergence of globalized individuals who share a responsibility to the globe and participate in global collective action.

10) George 1977; Prempeh 2004.

11) Langman 2005.

12) Robertson 1992; Thompson 1995; Wapner 1995; Keck and Sikkink 1998.

13) Cleaver 1998; Olesen 2005; McDonald 2006. 
This convergence thesis is not without its detractors, however. However intuitive the thesis may appear, it often invites skepticism from those who do not see a convergence in the motivations and psychological dispositions of global social movement participants. They claim that today's global social movements are a collection of discrete movement activities, with little in-depth intentional connections across them. One reason is that newly developed computer-mediated communication tools within organizations and communication structures, such as the Internet, is now normal. The Internet, they argue, does little more than make effective use of the contents already existing in the communicational routes in and across the organizations. ${ }^{14}$

Interestingly, those who stand by this discrete thesis acknowledge a rapid increase in computer-mediated communication and the burgeoning movement networks covering over the globe. Yet, they negate the rise of shared awareness, common interpretations, and value convergence across participants of global social movements. While highly flexible in structure and adaptable to changing circumstances, movement networks are not organizations, and thus are unlikely to build a durable organization. ${ }^{15}$ The networked nature of the global movements effects the relationship among those participating in global collective action and their sense of collectivity. Bennett claims that networked organizations created by modern communication tools are at best connected by loosely structured ties, or "weak ties." ${ }^{16}$ In such organizational forms, cross-organizational ideological connection is thin, and thus unlikely to be the site where a new collective identity is formed out of their collaborative activities. Similarly, Gurak et al. pose a question on the substance of Internet protest, claiming that its nonhierarchical nature may make it difficult to constitute meaningful participation. ${ }^{17}$

This discrete thesis finds an echo in the globalization- nationalism debate. Contrary to the claims of increasing cultural standardization and value convergence in the coming age, ${ }^{18} \mathrm{Smith}$ argues that national cultures will not fade away even in the era of globalization. ${ }^{19}$ National culture is particular and time bound, and is a strong correlate with the national identity

14) Davis 1999; Agre 2002.

15) Fox and Brown 1998; della Porta et al. 2006.

16) Bennett 2003.

17) Gurak et al. 2003.

18) Kriesberg 1997.

19) Smith 1990. 
that history has formed. In fact, national culture is built on the "ethnohistory" that contains symbols and myths that provide the salience of national history.

Both views find some support in the literature. This paper assesses the validity and applicability of these views through an examination of participants' mentality in the World Peace Now (WPN) movement, a Japanese peace movement that started in 2002 and continues up to the present.

\section{Research Design: Case and Data}

Selection of the World Peace Now (WPN) movement as a case for examination is based on its important features. First, it is a movement in pursuit of world peace, as the name implies. The nature of the movement goal constitutes an important qualification for a global movement. This orientation aligns the WPN with the other global social movements, such as human rights, anti-poverty and inequality, and environmental movements.

Second, the WPN has been in operation under a global network in coalition with each other. Ever since its inception in 2002, WPN has had close contact with overseas organizations seeking global peace, such as Stop the War Coalition and International ANSWER (Act Now to Stop War and End Racism), and frequently organized its campaigns in accordance with worldwide anti-war and peace actions. Its effort to synchronize and coordinate the actions with the global campaigns shows its inclination and desire to be part of the global peace movements.

Third, the magnitude of the worldwide anti-Iraq war campaign, which the WPN has been part of, should also be mentioned. For example, on March 22, 2003, an estimated 2.2 million people took to the street only in the US and Europe.$^{20}$ At the height of the campaign, it mobilized tens of million people in some sixty countries. The geographic coverage and magnitude of participants involved in this world campaign should qualify the movement as a global one.

In Japan too, the anti-Iraq war protest carried its significance. The WPN, specifically in its early stage of coalition activity, was able to mobilize some tens of thousands of participants in the Tokyo area in one day. While on a smaller scale than the events typically observed in some European and North American countries, a campaign of this magnitude was the largest

20) Lee 2003. 
among demonstration activities in Japan since the early 1990s. A large turnout implies the extent of the significance that the WPN movement had on Japanese citizens; at a minimum, it shows that it is not a movement to be neglected.

Data used in this research were collected using three different techniques: interviews, printed materials, and a questionnaire survey. Two sequences of interviews were conducted. The first one was distributed in May and June of 2003 to five members of a Japanese civil group, called Group J in this paper. Group J is also a constituting member of the WPN coalition. The informants provided detailed processes of their failed negotiation with a Korean civil group in their effort to create an overarching coalition between Japanese anti-war movements and Korean counterparts. Both groups participated in the worldwide anti-Iraq war campaign in 2003 and 2004. In this paper, this dataset is used to illustrate differential historical interpretations and future action orientations of these groups and subsequent difficulties in coalition building.

The second sequence of interviews was conducted during the demonstration campaigns in Tokyo, January 25, 2004, with sixteen campaign participants. ${ }^{21}$ Interviewees were asked about their evaluation of the significance of the campaign, and their motivation to participate. Of particular interest were the motives that led them to participate (why do you participate?), and the significance behind the motivations (how did you come to understand that your stated reason to participate was important?). Data acquired through interviews were intended to gauge causal attribution processes of participation motives at an individual level; they are used to evaluate interviewees' meaning attribution process to the act of participation, and to examine the extent of global mentality in participants' motives.

To gauge the motives and signification to the act of protest of general participants and conscientious constituents at a collective level, printed materials, mainly newspaper articles and written pamphlets, were also collected during September 2002 through May 2003. Articles and statements whose discussions were centered on the theme of peace and anti-war were the focus of the data gathering. Special attention was paid to the discussions that would relate the pursuit of peace to its reasons and motivations at a collective level. In the analysis, these data were analyzed with the

21) Interviewees were not asked to identify their ages. However, five appeared over age 60, seven in their 30s through 50s, and four under age 30. 
emphasis on possible revelation of the motivations of the peace action at the communal, national, and global level.

A final dataset used in the paper comes from the demonstration survey conducted in Tokyo in April 5th and 12th, 2003. In the survey, respondents were asked about their political attitudes, their networks and associated organizations, and their source of information on political activities. ${ }^{22}$ While the survey was conducted in conjunction with a different research project, the data tapped on the topics that were of concern to the present paper, specifically on the demographic aspects of those constituting the peace protest campaigns. In the analysis, these demographic data were used mainly to examine the general applicability of the arguments put forth in the paper.

In the next section, the paper discusses the characteristics of the WPN campaign, and then proceeds to an examination of mental dispositions of those involved in the WPN campaign in the subsequent section.

\section{Peace Movement in Japan: "World Peace Now"}

On March 8, 2003, in Tokyo, some 50,000 people took to the street and raised their voice, "Sensou Hantai," that is, "No War". To an imminent threat of the war against Iraq, a number of people in Japan responded by joining a large protest action. Wearing colorful outfits, carrying signs and musical instruments as they pleased, they gathered and joined the parade. This was seen not only in Tokyo, but also the same action was also seen in other cities and towns in Japan, including Sapporo, Osaka, Kyoto, Nagoya, Fukuoka, and Hiroshima and Nagasaki, to name some.

In Japan, as in many other countries, 9/11 and the subsequent response from the US government set the tone of peace protest activities thereafter. Immediately after $9 / 11$, a so-called "peace action" or "peace parade" began to be organized in scattered locations in succession. This series of protests gradually became a surge, with large waves formed in January and March in 2003, and again January and March in 2004.

\footnotetext{
22) Seven hundred questionnaires were delivered to the participants on the demonstration scenes. Of those, 308 were retuned, with the response rate of $44 \%$. After data-cleaning and omission of questionable cases, this paper uses 303 cases in maximum. Total numbers in the subsections of Table 1 vary depending on the number of missing cases. For the sampling procedure, this project followed demonstration survey technique developed by Van Aelst, Norris, and Walgrave (Van Aelst et al 2001; Norris et al. 2005).
} 
A major group leading these actions was "World Peace Now" (WPN). WPN is a coalition of some 50 groups, including civil groups and NGOs, such as peace movement groups, human rights organizations, and environmental groups. WPN started with a coalition of a few groups in October 2002. In January, 2003, it staged a large coordinated action across all of Japan, which transformed it into its present iteration.

It is rare, at least in Japanese history, to see a number of groups and organizations flocking together and coordinating a peace action of this magnitude in a short period of time. Behind this coalition was the imminent threat of war against Iraq. A sense of urgency constituted the basis for a quick consensual formation of a large coalition that was to lead the peace movement in Japan.

One feature that characterizes the campaign is the size. Particularly in the early stage of the campaign, the volume of participants in this campaign was large. The numbers were not comparable to those seen in peace actions in some European countries and in the US. However, the demonstration was large in post-war Japanese movement history, and by far the largest of any demonstration activities that took place in the last two decades. Figure 1 shows that WPN, at its height, staged actions continuously, oftentimes gathering crowds into the tens of thousands.

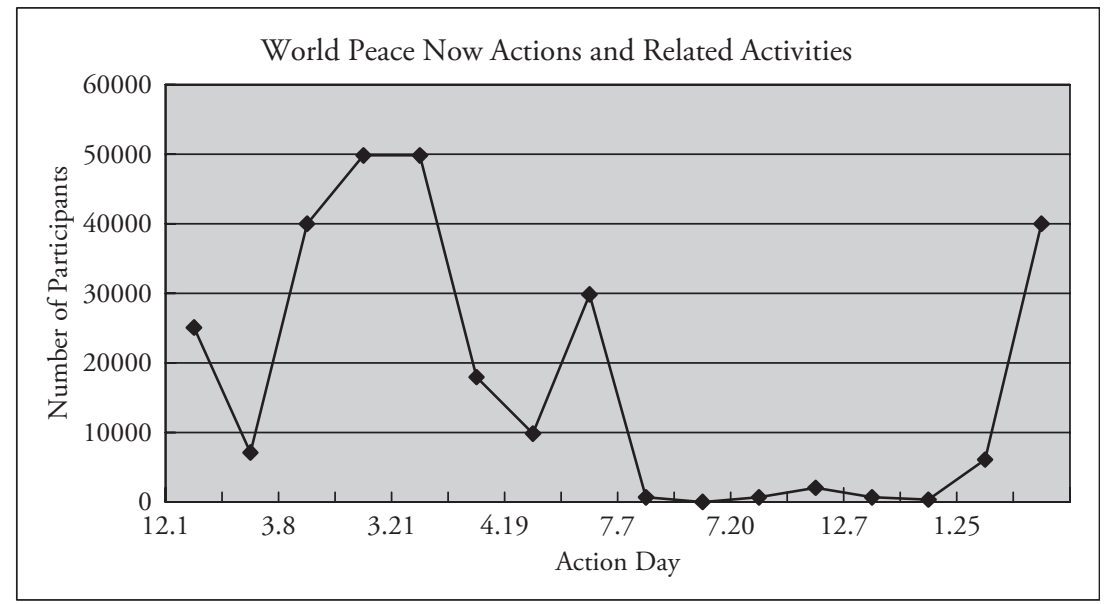

(Source: Takada (2004))

Figure 1 Number of Participants in WPN demonstrations (December 2002-March 2004, Tokyo, Japan) 
Both the magnitude and the people constituting the campaign action are noteworthy because they draw new categories of participants. The mass media observed that the demonstrations drew people in who were young, ordinary, and not necessarily connected to civil society organizations. One newspaper writes, "What was surprising in this demonstration were the participants; many were young people participating individually, families with children, and those joining a demonstration for the first time. At last, ordinary people have emerged as the leading player." ${ }^{23}$ During the "Ice Age of social movements" from the late 1970s to the late 1990s in Japan, save for a few cases, high school and college students were not present in mass demonstrations and campaigns. Families and ordinary people also receded from the movement track. Only lifetime activists and persistent members of vocational-functional organizations, such as trade unions, were left taking to the street. Thus, in a sense, the WPN campaign created a new opportunity for those categories of people to be back in campaign activities.

This coincides with the findings in our demonstration survey results (Table 1). About $40 \%$ of all demonstrators were individual participants, with no connection whatever to any civil society groups or vocationalfunctional organizations. Participants typically use the Internet and personal networks as their sources of information for the dates and locations of peace actions and rallies. Age cohort distribution also shows that about $33 \%$ of the participants are in their 20s and 30s, suggesting that the young are well represented in the parade. ${ }^{24}$ These participants also have relatively shallow record of previous demonstration experiences. Table 2 shows that $57 \%$ of participants have participated in fewer than five previous demonstrations. The same figure rises up to $83 \%$ in the individual participation category, implying that peace demonstrations drew inexperienced individuals to the streets.

An important feature attributed to the WPN campaign - the one most relevant for our purposes - is its extent of global reach. This characterization comes from the movement's resilient alliances with campaigns around the world. For instance, on March 20, 2004, when Stop the War Coalition issued a call for a globally coordinated action, the WPN responded by coordinating domestic actions. In the subsequent week, too, it mobilized 40,000 people for protest actions across the country. From December

\footnotetext{
23) Oguni 2003.

24) Of the participants under the age 29 , more than $50 \%$ were individual participants, suggesting that a young participant was likely to be an individual participant
} 
2002 to March 2004, the WPN had organized globally coordinated actions six times, piggybacking off of worldwide campaigns.

Behind this frequent coordination of with global actions were preestablished exchange ties with personnel in overseas movement organizations. The WPN, when it was established, already had some international connections, as some of its leading members had carried with them past exchange experiences with foreign groups such as the International ANSWER, Stop the War Coalition, and Peaceful Tomorrows. Thus WPN has become a major organizational network in Japan that receives a call for a globally coordinated action from overseas. Added to this is the WPN effort to don an international flavor, often featuring foreign guest speakers such as US Congresswoman Barbara Lee.

WPN is also said to have participants with global orientations and connections. February 15, 2003, was an ironic illustration of these global connections. On that date, major Japanese civil society groups and labor organizations failed to stage a coordinated action in line with world peace campaigns. The result was a relatively small smattering of gatherings in cities and towns around Japan. However, many, especially those unconnected to active and involved organizations, took to the street independently, thinking that there should be some gatherings and marches somewhere that they could possibly join. These people had taken information on protest action from global sources and thought that Japanese people would also join this one-day global coalition campaign. This incident illustrates the global connection of individuals through the Internet and also a global orientation. These participants looked to actions organized globally and changed the outcome of protest events in Japan, despite organizational agnosticism.

WPN may well be viewed as a global social movement. We may note, however, that this characterization of the movement is based on a structural aspect of the movement, specifically regarding its integration to and coordination with peace campaigns that run through the global surface. The same movement takes quite a different outlook, once we turn to an examination of the motivational aspects of movement participants.

\section{Motives and Meaning Attribution behind Protest Action}

An assessment of the motives for movement action necessitates an examination of the meanings attributed by the participants and conscientious 
Table 1 General Attributes of Participants

\begin{tabular}{|c|c|c|c|c|c|}
\hline & & $\begin{array}{l}\text { individual } \\
\text { participant }\end{array}$ & citizen group & $\begin{array}{l}\text { professional } \\
\text { group }\end{array}$ & Total \\
\hline \multirow[t]{2}{*}{ Gender } & Male & $\begin{array}{l}35 \\
(31.3 \%)\end{array}$ & $\begin{array}{l}37 \\
(35.2 \%)\end{array}$ & $\begin{array}{l}54 \\
(62.8 \%)\end{array}$ & $\begin{array}{l}126 \\
(41.6 \%)\end{array}$ \\
\hline & Female & $\begin{array}{l}77 \\
(68.8 \%)\end{array}$ & $\begin{array}{l}68 \\
(64.8 \%)\end{array}$ & $\begin{array}{l}32 \\
(37.2 \%)\end{array}$ & $\begin{array}{l}177 \\
(58.4 \%)\end{array}$ \\
\hline \multirow[t]{5}{*}{ Age } & under 30 & $\begin{array}{l}24 \\
(21.4 \%)\end{array}$ & $\begin{array}{l}13 \\
(12.4 \%)\end{array}$ & $\begin{array}{l}9 \\
(10.6 \%)\end{array}$ & $\begin{array}{l}46 \\
(15.2 \%)\end{array}$ \\
\hline & $30-39$ & $\begin{array}{l}19 \\
(17.0 \%)\end{array}$ & $\begin{array}{l}22 \\
(21.0 \%)\end{array}$ & $\begin{array}{l}12 \\
(14.1 \%)\end{array}$ & $\begin{array}{l}53 \\
(17.5 \%)\end{array}$ \\
\hline & $40-49$ & $\begin{array}{l}32 \\
(28.6 \%)\end{array}$ & $\begin{array}{l}23 \\
(21.9 \%)\end{array}$ & $\begin{array}{l}24 \\
(28.2 \%)\end{array}$ & $\begin{array}{l}79 \\
(26.2 \%)\end{array}$ \\
\hline & $50-59$ & $\begin{array}{l}30 \\
(26.8 \%)\end{array}$ & $\begin{array}{l}27 \\
(25.7 \%)\end{array}$ & $\begin{array}{l}35 \\
(41.2 \%)\end{array}$ & $\begin{array}{l}92 \\
(30.5 \%)\end{array}$ \\
\hline & over 60 & $\begin{array}{l}7 \\
(6.3 \%)\end{array}$ & $\begin{array}{l}20 \\
(19.0 \%)\end{array}$ & $\begin{array}{l}5 \\
(5.9 \%)\end{array}$ & $\begin{array}{l}32 \\
(10.6 \%)\end{array}$ \\
\hline \multirow[t]{9}{*}{ occupation } & Manual & $\begin{array}{l}6 \\
(5.4 \%)\end{array}$ & $\begin{array}{l}4 \\
(3.8 \%)\end{array}$ & $\begin{array}{l}3 \\
(3.5 \%)\end{array}$ & $\begin{array}{l}13 \\
(4.3 \%)\end{array}$ \\
\hline & Non-manual & $\begin{array}{l}13 \\
(11.7 \%)\end{array}$ & $\begin{array}{l}21 \\
(20.0 \%)\end{array}$ & $\begin{array}{l}43 \\
(50.6 \%)\end{array}$ & $\begin{array}{l}77 \\
(25.6 \%)\end{array}$ \\
\hline & Management & $\begin{array}{l}5 \\
(4.5 \%)\end{array}$ & $\begin{array}{l}4 \\
(3.8 \%)\end{array}$ & $\begin{array}{l}5 \\
(5.9 \%)\end{array}$ & $\begin{array}{l}14 \\
(4.7 \%)\end{array}$ \\
\hline & Professional & $\begin{array}{l}40 \\
(36.0 \%)\end{array}$ & $\begin{array}{l}35 \\
(33.3 \%)\end{array}$ & $\begin{array}{l}23 \\
(27.1 \%)\end{array}$ & $\begin{array}{l}98 \\
(32.6 \%)\end{array}$ \\
\hline & self employed & $\begin{array}{l}3 \\
(2.7 \%)\end{array}$ & $\begin{array}{l}3 \\
(2.9 \%)\end{array}$ & $\begin{array}{l}2 \\
(2.4 \%)\end{array}$ & $\begin{array}{l}8 \\
(2.7 \%)\end{array}$ \\
\hline & Retirement & $\begin{array}{l}18 \\
(16.2 \%)\end{array}$ & $\begin{array}{l}18 \\
(17.1 \%)\end{array}$ & $\begin{array}{l}5 \\
(5.9 \%)\end{array}$ & $\begin{array}{l}41 \\
(13.6 \%)\end{array}$ \\
\hline & Housewife & $\begin{array}{l}12 \\
(10.8 \%)\end{array}$ & $\begin{array}{l}13 \\
(12.4 \%)\end{array}$ & $\begin{array}{l}0 \\
(0.0 \%)\end{array}$ & $\begin{array}{l}25 \\
(8.3 \%)\end{array}$ \\
\hline & Student & $\begin{array}{l}13 \\
(11.7 \%)\end{array}$ & $\begin{array}{l}7 \\
(6.7 \%)\end{array}$ & $\begin{array}{l}2 \\
(2.4 \%)\end{array}$ & $\begin{array}{l}22 \\
(7.3 \%)\end{array}$ \\
\hline & Else & $\begin{array}{l}1 \\
(0.9 \%)\end{array}$ & $\begin{array}{l}0 \\
(0.0 \%)\end{array}$ & $\begin{array}{l}2 \\
(2.4 \%)\end{array}$ & $\begin{array}{l}3 \\
(1.0 \%)\end{array}$ \\
\hline
\end{tabular}


Table 1 (cont.)

\begin{tabular}{llllll}
\hline & & $\begin{array}{c}\text { individual } \\
\text { participant }\end{array}$ & citizen group & $\begin{array}{c}\text { professional } \\
\text { group }\end{array}$ & Total \\
\hline education & under high school & 13 & 22 & 16 & 51 \\
& & $(10.7 \%)$ & $(21.0 \%)$ & $(18.6 \%)$ & $(16.8 \%)$ \\
& Vocational school & 10 & 11 & 1 & 22 \\
& & $(8.9 \%)$ & $(10.5 \%)$ & $(1.2 \%)$ & $(7.3 \%)$ \\
& junior college & 17 & 14 & 7 & 38 \\
& & $(15.2 \%)$ & $(13.3 \%)$ & $(8.1 \%)$ & $(12.5 \%)$ \\
& University and & 72 & 56 & 62 & 190 \\
Sum & graduate school & $(64.3 \%)$ & $(53.3 \%)$ & $(72.1 \%)$ & $(62.7 \%)$ \\
\hline $\mathrm{N}$ & $(100.0 \%)$ & $(100.0 \%)$ & $(100.0 \%)$ & $(100.0 \%)$ \\
\hline
\end{tabular}

(Source: Peace Protest Survey, April 2004, Tokyo)

Table 2 Past Experience of Participation (percentage)

\begin{tabular}{lcccc}
\hline & $\begin{array}{c}\text { individual } \\
\text { participant }\end{array}$ & citizen group & $\begin{array}{c}\text { professional } \\
\text { group }\end{array}$ & Total \\
\hline first time & 20.7 & 4.8 & 5.7 & 10.9 \\
1-5 times & 62.2 & 47.1 & 23.0 & 45.7 \\
6-10 times & 29.4 & 17.3 & 20.7 & 16.9 \\
11-20 times & 0.0 & 16.3 & 17.2 & 10.6 \\
over 20 times & 3.6 & 14.4 & 33.3 & 15.9 \\
\hline Sum & 100.0 & 100.0 & 100.0 & 100.0 \\
N & 111 & 104 & 87 & 302 \\
\hline
\end{tabular}

(Source: Peace Protest Survey, April 2004, Tokyo)

supporters to their protest action. To explore the meaning attribution processes, observations both at an individual level and a collective level are necessary. To understand how participants signify their act of participation and where they derive the meaning of the action, interviews were conducted to participating individuals during the parade in January 25, 2004. To explore collective meaning attribution processes, newspaper articles and pamphlets were gathered with special attention to the statements and 
claims providing a rationale to participate the cause at a community, nation, regional, and global level.

\section{Meaning Attribution from Local History}

Interviews reveal that for many, motives for participation are linked to past experiences, both direct and indirect. The elderly, in particular, justify their protests out of a fear of the misery and difficulties that are sometimes brought by war. These are the very difficulties that they themselves experienced during and after WWII and which they would like this generation to avoid. ${ }^{25}$ One male interviewee whose age appeared over 70 said:

You do not know what war is about. It is far beyond the imagination of people's everyday lives. I came here by myself because I felt I needed to tell young people my experiences of fear and misery in the war.

Interviews with those in their 30s through 50 s reveal that they often associate their participation motives to imagined consequences of war. This is natural in that they do not have direct experiences of war. What is most intriguing, however, is that they often employ family experience as a frame of reference for imagining and understanding the consequences of war. A female interviewee, who endured a two-hour train ride to reach the march, relayed a story that she heard from her uncle when she was a high school student:

My uncle told me a story of his experience. During the war, one day when he was working on his land on his farm, suddenly the sound of a fighter plane came from behind and attacked him. The airplane fired aiming at the ground. During the attack, all he could do was to lay on the ground stooped, praying only that the attack would soon end. He said that he felt that the attack would go on forever.

This portion of the story coincided with the emotion the former male interviewee referred to as fear. The female interviewee did not stop there, however. She went on to tell the latter part of her uncle's story, which she appeared to think important for her motivation to join the action.

25) An extraction of the meaning attributed to the act of protest from direct personal experiences is also observed in those not present in the demonstration. A poet in his 80 s, Inoue (2003), replying to the reporter in the newspaper interview, says that the Iraq war overlaps his experience of war. 
Well, my uncle then ran back home, to see his house hit by the attack. On the way, all he could think about was what he would do if his family had been hit. I did not fully understand the meaning and importance of the story when I first listened to it. Now that I have my family, I do.

Another female interviewee, who appeared to be an acquaintance of the above female interviewee, exposed her determination for participation in a similar manner. "We shout, we will not let anyone attack our family and children."

They first ask themselves the question, "what might happen to my family and my children if war breaks out," and then reach an empathic understanding of the feeling of those who experienced the war first hand. Behind this empathic understanding stand stories and narratives of those who are very close to them, such as their parents, grand-parents, and their relatives who have had direct experiences of war. In other words, those in middle age tend to draw implications and meaning of war from empathetic understanding using the narratives of their family experiences one or two generations ago. Whether they marshal direct or indirect experiences in their stories, they refer to the past, specifically the Japanese experience during WWI and II.

Closely related to individual-level mobilization, but an analytically different dimension altogether, is collective memory. The words "Hiroshima" and "Nagasaki" symbolize a particular Japanese collective memory and carry with them special meanings. Many and different interpretations have been attributed to these terms, but a major interpretation shared widely among Japanese people is a sudden misfortune. It is a misfortune in the sense that the attack hit innocent people living ordinary and everyday lives, who had never imagined of dying and having serious illness. This interpretation is distinct from the logic and ideas typically employed in academic study, especially in the area of international relations and the world history. Here, detailed discussions abound to explain how international relations evolved to the point where atomic bombs were dropped on these two cities, Hiroshima and Nagasaki. Instead, for many Japanese people, the terms "Hiroshima" and "Nagasaki" implicate the thoughts and understandings of war from the perspective of those exposed to an atomic bomb. As a collective memory, it means the death of an innocent, and it attains this by emphasizing less the logic of international politics.

This collective interpretation of Hiroshima and Nagasaki constitutes the basic core component of the Japanese interpretation of war. During protest 
marches, participants chant, "No War," not "No the war against For them, war of any kind, leads to the death of innocent people.

The collective memory of Hiroshima and Nagasaki is equally shared by conscientious constituents of the contemporary peace movement in Japan. Tsurumi, an influential thinker who led the anti-war campaign in $1960 \mathrm{~s}$ Japan, claimed before the advent of the Iraqi War that Japan should deliver a strong and loud voice against war if it involves the possibility of a nuclear war. It was because, he said, Japan is the only country that has experienced the nuclear bomb. ${ }^{26}$

Ohe, a nobel-prize winner and influential writer, argues that today's peace movement in Japan should start from Hiroshima, that is, a shared memory about Hiroshima and Nagasaki. Behind this argument is his understanding that peace protest against war should base its theoretical and interpretive foundation on the death of the innocent. ${ }^{27}$ Whatever this interpretation may involve, it is clear that he carries with him a collective memory of Hiroshima and Nagasaki and associates it with the current peace movement. ${ }^{28}$

The above discussion centers on the motives, meanings, and interpretive frames, and may thus be evaluated as having no empirical and observational grounds. While it is certainly difficult to find empirical evidence corresponding to human motives, we have some pieces that partially corroborate the above arguments.

One strong characteristic deriving from the above interpretation is that participants and sympathizers alike build their claim on everyday thinking of the commons. Emotions such as fear and misery, attained either through direct past experiences or empathetic and imaginary interpretations of the feelings of those in the war, are feelings often associated with women. This is resoundingly so in Japan, a country with relatively strong male dominance apparent in various areas such as politics and economics. Women are pushed into being more emotive, domestic, and pedestrian. Since this is the case in Japan, we might expect more women than men in the Japanese peace movement, especially among those who come along with no ties to a civil society or labor organization.

\footnotetext{
26) Tsurumi 2003.

27) Ohe 2002.

28) Ohe further goes on to associate Hiroshima with 9.11, claiming that Hiroshima was Japan's Ground Zero. This extended use of Japanese collective memory to interpret an incident overseas shows how Hiroshima strong influences his interpretive framework.
} 
Table 1 shows that this is more or less the case. Of all the participants, female constitute $58 \%$, as opposed to $42 \%$ male. This tendency becomes much more apparent when it comes down to those participating individually and as members of civil groups. The numbers rise to $69 \%$ and $65 \%$ respectively.

This speculation also coincides with an observation by another famous writer. Setouchi Jyakucho, herself a nun, speaks of her privately-issued report, comments that more females than males respond to her call to stage an unitary voice that any war is wrong..$^{29}$ The strong influence of local and historical memories on the motivations of the elderly to participate should also manifest itself in the survey findings. Table 1 shows that $41 \%$ of participants are over age 50 . Of those, $67 \%$ are participants who either join the action independently, or come as members of citizen groups. Unlike those in professional organizations, they are generally not obligated nor pressured to participate. Rather they decide their participation on an individual basis. Again, these numbers corroborate the above findings.

At an individual level, the elderly derive their motivations to participation from their direct experiences. Those in middle age rely on empathetic understanding of war. They understand the possible consequences of war, particularly on their family, and then use this to inform their motivations for participation. At a collective level, Japanese collective memory and interpretations of Hiroshima and Nagasaki form a substantial part of spiritual background for the WPN campaign.

Observations of motives for participation and meaning attribution processes reveal an astoundingly localized and historical nature of the WPN coalition. None of the interviews found a motivation for participation having to do with the interviewee's self recognition as a global citizen, or his/her global awareness. Newspapers and pamphlets heavily cite past Japanese experiences as a referent point for the peace action.

The Peace campaign in Japan runs parallel to the global peace movement; it synchronizes activities with global waves of protest. Yet its nature is astoundingly localized and historically driven. The movement is local in a sense that motives for participation to global action, together with their interpretive referent, derive from the experiences as Japanese, not from as global citizens. It is also historical in a sense that these motives are the direct and indirect reflections of the experiences rooted deep in Japan's historical past.

29) Setouchi 2003. 
The local and historical nature of the Japanese global movement poses a puzzle for us, since the global and the local-historical should not exist without interference with each other. At a minimum, we can infer that the historically rooted nature of the movement should affect the direction of the global movement. At least it must limit the possibilities that the global movement barrels toward. But the dominant characteristics of Japan's contemporary peace movement reveal themselves in other ways as well.

To examine this, we now turn to another instance of WPN activities. The case discussed next is a series of discussions and negotiations between one civil society group of the WPN coalition and a Korean counterpart also constituting a major anti-war and peace movement coalition in South Korea. For the sake of convenience, we call the Japanese organization Group J and Korean counterpart Group K.

\section{Local Discrepancies under Global Success}

During the Iraqi War, a certain anxiety started to hover over the Pacific region: a possible war against North Korea. An announcement by North Korea to withdraw from the Treaty on the Non-Proliferation of Nuclear Weapons (NPT) earlier in 2003 stirred up the international political scene. This, together with President Bush's characterization of Iran, Iraq, and North Korea as the Axis of Evil resulted in apprehension for another instance of war. To this political situation, a civil society organization in Japan responded. Group J, one of the leading groups in the WPN coalition, sought a cooperative relationship with a similar peace movement group in South Korea.

This move was in line with Group J's future plan to establish a grand coalition of peace movements among countries surrounding the Pacific Rim, namely, South Korea, the U.S., and Japan, and was placed as strategically important for the construction of a future global coalition. The result, however, was a failure.

Differences in the perception of North Korea and in interpretations of history contributed to this failure. One difference was on the evaluation of North Korea's political and social situation. While Group J believed that North Korea was under a political dictatorship structure, and carried some features of a secret state by concealing incidences of human rights violation, its South Korean counterpart claimed that North Korea was not in itself an evil society. Many of the social and political problems came from the separation between North and South, and thus these problems should 
be solved by unification. The South Korean counterpart also took Group J's argument as inadequate, claiming that it would be ethically inconceivable to see Japanese people pointing out incidences of human rights violation of other countries.

There was also a difference on the issue of nuclear weapons. While Group J thought it natural and easily justified to include nuclear non-proliferation claims in the peace movement agenda, the Korean counterpart did not. For the Korean counterpart, incorporating nuclear nonproliferation claims in the peace movement agenda would need more explicit justification. ${ }^{30}$

It is easy to see that behind these discrepancies in their claims and arguments lie different historical pasts. For Group J, an atomic bomb is an instant association with war-making. A number of people in Japan believe themselves to be the only people in human history that have suffered from an atomic bomb. Thus came the claim by Group J that a slogan to abandon nuclear weapons should be among the most important arguments they put forward in peace movement activities. For Group K, unification of the North and South is overwhelmingly an important goal of the movement, which if realized would solve a majority of the problems North Korea was facing. Thus came group K's stance that politically and socially evaluating the so-called "dark side" of North Korea was inappropriate.

In the exchange, an overriding historical past between Japan and South Korea was observed, namely, the Japanese invasion of Korea and its annexation in the early 20th century. This past was well cast in Group K's response to Group J's definition of North Korea as involved in incidences of human rights violations. Group K instead questioned the legitimacy of Group J's attitude in denouncing North Korea. Group K claimed that the Japanese group was doing so at the expense of tucking away Japan's past wrongs.

Differences between peace movement organizations across borders are huge. There are enormous differences in the evaluation of the region's political and social situations, and in their main goals and claims of the movement activities. These differences, which are strongly associated with the historical past, can shut down the possibility of cross-national cooperation among otherwise sympathetic movement organizations.

One intriguing fact is that both Groups $\mathrm{J}$ and $\mathrm{K}$, and the movement networks that they are part of, have successfully engaged themselves in

\footnotetext{
30) Interviews with Group J's members 2003.
} 
global campaigns. They have acted in accordance with international calls for worldwide coordinated actions. This may mean that the fate of a contemporary global social movement may stand on the alliance or non-alliance of movement organizations with mutually uncompromising historical legacies. Movements across borders are not only diverse, but often heterogeneous and conflicting enough to promote a divide or shut down a possibility for future cooperation.

\section{Conclusion}

The task of the paper was to explore the nature of a current global social movement. Scholars differ in their characterization of the motivational aspects of global activism. Using a Japanese global movement campaign, the World Peace Now, this article attempted to reveal participants' motives by focusing on the sources of meaning and processes of meaning attribution reflected in their participation.

In contrast to those scholars that stress the "global" in global social movements, the results underscore the critical importance of the local and historical in such movements. Participants of the WPN campaign derive the motivation to participate from their personal experiences, and Japanese historical incidents and their localized interpretations. Personal and family narratives at an individual level and collective memory of Hiroshima and Nagasaki at a national level played an important role in this meaning attribution process. Using the narratives and the collectively rehearsed memory of the past, participants are able to extract the meaning of, and a justification for, the action.

This signification process, made up of local and historical legacies, is generally indifferent to the global appeals. Few elements associating the participation motives to the globe are found in the WPN campaign. The current Japanese social movement, despite its global outlook, is local and historically driven in its motivational make-up. It is local and historical because it extracts its motives from personal experiences and idiosyncratic historical past.

Looking beyond this conclusion, the paper provides an opportunity for speculation. Given that the motives of current Japanese peace movement are locally and historically constructed, how is a global social movement possible?

While the Japanese peace movement has had success in connecting itself to the world-wide global campaign, it has failed to create a regional bilat- 
eral coalition. Apparently, this is a contradiction, given that we use the term "global" to characterize modern social movements that cover much of the globe. At a minimum, this contradiction implies some conditions or limitations posed on to the present global movement.

In my observation, one important condition is "surface interaction." By "surface interaction" I mean exchanges and discussions that flow only on the surface of the relationship among movement groups under negotiation processes. In the exchange between Japanese and South Korean movement groups, discussions went deep under the surface to provoke arguments about historical past and emotional responses. It is likely that discussions based on historical differences will lead to an opportunity to reveal differences in the perceptions and interpretations about current socio-political circumstances and a related past, and thus to the presence of potential obstacles for further coalition-building. Such differences would soon pile up if deep discussions ensue, given the volume of countries and active organizations within each country being engaged to create a "global" protest action. Surface interaction helps minimize the chances that grave differences rooted in history and in other socio-political conditions will emerge.

In theoretical terms, the concept of "surface interaction" may shed light on a functional aspect of the nature of interaction among movement groups in a coordinated action. As we saw earlier in this paper, some scholars discussing the network nature of coordinated action predict the spread of shared beliefs and consciousness together with deepening mutual understanding among partners. From this perspective, the idea of surface interaction is counter-intuitive, as it predicts that the relationship and interaction cannot go deep among groups engaging in global coalitions.

Nor does it promote a sense of collective identity. Scholars have identified an emerging global collective identity as one important feature of modern social movement. ${ }^{31}$ Also students of globalization have pointed out the development of global mentalities, where individuals have global awareness and an understanding of themselves as "global citizen," together with the understanding of the world as a "global village." The notion of surface interaction implies otherwise. In this paper, there is little that enables us to see the nourishment of a type of collectivity that would go beyond superficial connections. Differences and discrepancies abound even among peace movement organizations and their participants in two countries residing

31) e.g. Farro and Vaillancourt 2001; Drury et al 2003. 
nearby each other. An image of "global citizens" participating and nurturing global collective identity seems a misleading description of at least this particular global movement.

The idea of surface interaction and its implications, including bleak prospects for the emergence of global collective identity, need further examination and verification before it can be usefully wielded in any meaningful sense. Nonetheless, it serves as a useful heuristic.

\section{References}

Agre, Philip 2002, "Real-Time Politics: The Internet and the Political Process." Information Society 18(5): 311-331.

Albrow, Martin 1996, The Global Age: State and Society beyond Modernity. Cambridge. UK: Polity Press.

Bennett, W. Lance 2003, "Communicating Global Activism: Strengths and Vulnerabilities of Networked Politics." Information, Communication, and Society 6(2): 143-68.

Brecher, Jeremy, Tim Costello, and Brendan Smith 2000, Globalization from Below: The Power of Solidarity. Cambridge, England: South End Press.

Buttel, Frederick H 2003, "Some Observations on the Anti-Globalisation Movement" Australian Journal of Social Issues 38(1):95-116.

Buttel, Frederick H. and Kenneth Gould A. 2004, "Global Social Movement(s) at the Crossroads: Some Observations on the Trajectory of the Anti-Corporate Globalization Movement." Journal of World-Systems Research 10(1):37-66.

Cleaver, Harry M. Jr. 1998, "The Zapatista effect: the Internet and the rise of an alternative political fabric.” Journal of International Affairs 51(2):621-640.

Davis, Richard 1999, The Web of Politics: the Internet's Impact on the American Political System. New York: Oxford University Press.

Della Porta, Donatella, Massimiliano Andretta, Lorenzo Mosca, Herbert Reiter 2006, Globalization from Below: Transnational Activities and Protest Networks. Minneapolis: University of Minnesota Press.

Diani, Mario and Doug McAdam (eds.) 2003, Social Movements and Networks: Relational Approaches to Collective Action. New York: Oxford University Press.

Drury, John, Steve Reicher, and Clifford Stott 2003, "Transforming the Boundaries of Collective Identity: the "Local" Anti-road Campaign to "Global" Resistance?" Social Movement Studies 2:191-212.

Farro, Antimo and Jean-Guy Vaillancourt 2001, "Collective Movements and Globalization." Pp. 206-226. Hamel, Pierre, Henry Lustiger-Thaler, Jan Nederveen Pieterse, and Sasha Roseneil (eds.) Globalization and Social Movements. Palgrave Publishiers Ltd.

Fox, Jonathan A., and L. David Brown 1998, "Introduction." Pp. 1-47. Fox, Jonathan A., and L. David Brown (eds.) The Struggle for Accountability; The World Bank, NGOs, and Grassroots Movements. Cambridge, MA: MIT Press.

George, Susan 1977, How the Other Half Dies: the Real Reasons for World Hunger. N.J.: Allanheld, Osmun. 
Gurak, Laura J. and John Logie 2003, "Internet Protest, from Text to Web.” Pp. 25-46. McCaughey, Martha and Michael D. Ayers (eds.) Cyberactivism: Online Activism in Theory and Practice. New York and London: Routledge.

Hegedus, Zsuzsa 1989, "Social Movements and Social Change in Self-Creative Society: New Civil Initiatives in the International Arena.” International Sociology 4(1): 19-36.

Hovey, Michael W. 1997, "Interceding a the United Nations: The Human Right of Conscientious Objection.” Pp. 214-225. Smith, Jackie, Charles Chatfield, and Ron Pagnucco (eds.) Transnational Social Movements and Global Politics: Solidarity beyond the State. Syracuse University Press.

Inoue, Toshio 2003, "Listening to a Poet, Toshio Inoue: His Experience of Military Camp Overlaps the Iraq War (iraku sennsou to kasanaru jyuugunn taikenn: shijinn no inoue toshio sann ni kiku).” Asahi Newspaper. March 29, 2003.

Keck, Margaret E. and Kathryn Sikkink 1998, Activist Beyond Borders: Advocacy Networks in International Politics. Cornell University Press.

Kriesberg, Louis 1997, "Social Movements and Global Transformation." Pp. 3-18. Smith, Jackie, Charles Chatfield, and Ron Pagnucco (eds.) Transnational Social Movements and Global Politics: Solidarity beyond the State. Syracuse University Press.

Langman, Lauren 2005, "From Virtual Public Spheres to Global Justice: A Critical Theory of Internetworked Social Movements." Sociological Theory 23(1): 42-74.

Lee, Jennifer 2003, "The Nation: Critical Mass; How Protesters Mobilized So Many and So Nimbly" The New York Times, February 23, 2003.

McAdam, Doug and Rucht, Dieter 1993, "The Cross-National Diffusion of Movement Ideas." The Annals of the American Academy of Political and Social Science 528(1): $56-74$.

McDonald, Kevin 2006, “Zapatista Dreaming: Memory and the Mask.” Pp. 111-139. Global Movements: Action and Culture. Blackwell Publishing.

Moghadam, Valentine M. 2000, "Transnational Feminist Networks: Collective Action in an Era of Globalization.” International Sociology 15(1):57-85.

Norris, Pippa, Walgrave, Stefaan \& Van Aelst, Peter 2005, "Who Demonstrates? Anti-state Rebels or Conventional Participants or Everyone?” Comparative Politics 37(2): 189-206.

Oguni, Ayako 2003, "Peace Parade Spreading over Japan (nihon nimo hirogaru iraku kougeki hansen "heiwa pareido"." Mainichi Newspaper Feb.27 2003.

Ohe, Kenzaburo 2002, "From Ohe Kenzaburo to Mr. Johathan Schell (Ohe Kenzaburo kara Jonathan Schell shi he).” Asahi Newspaer October 9, 2002.

Olesen, Thomas 2005, International Zapatismo: The Construction of Solidarity in the Age of Globalization. London and New York: Zed Books.

Prempeh, E. Osei Kwadwo 2004, Anti-Globalization Forces, the Politics of Resistance, and Africa: Promises and Perils. Journal of Black Studies 34(4):580-598.

Robertson, Roland 1992, Globalization: Social Theory and Global Culture. London: Sage.

Rucht, Dieter 1999, "The Transnationalization of Social Movements: Trends, Causes, Problems.” Pp. 206-222. della Porta, Donatella, Hanspeter Kriesi, and Dieter Rucht (eds.) Social Movements in a Globalizing World. Mcmillan Press.

Setouchi, Jyakucho 2003, "War and Religion: Three Different Opinions (sensou to shuukyo: sansha san-yo).” Asahi Newspaer April 11, 2003.

Smith, Jackie 1997, "Characteristics of the Modern Transnational Social Movement Sector." Pp. 42-58. Jackie Smith, Charles Chatfield, and Ron Pagnucco (eds.) Transnational 
Social Movements and Global Politics: Solidarity beyond the State. New York: Syracuse University Press.

Spybey, Tony 1996, Globalization and World Society. Cambridge, MA : Polity Press.

Takada, Ken 2004, "World Peace Now: Chronological Table of Gatherings and Related Activities (WPN kankei shu-ukai nenpo)." Personal Documents.

Thompson, John B. 1995, The Media and Modernity. Cambridge: Cambridge University Press.

Tsurumi, Shunsuke 2003, "Based on the fear "We do not want to be killed": A New Form seen in Anti-Iraqi War Movement (korosaretaku nai wo konkyo ni: iraqu hansen undo ni miru atarashi katach)." Asahi Newspaper March 24, 2003.

Van Aelst, Peter \& Walgrave, Stefaan 2001, "Who Is That (Wo)man in the Street?: From the Normalisation of Protest to the Normalisation of the Protester." European Journal of Political Research 39: 461-486.

Wapner, Paul 1995, "Politics Beyond the State: Environmental Activism and World Civil Politics," World Politics 47(3):311-340. 
Copyright of Societies Without Borders is the property of Brill Academic Publishers and its content may not be copied or emailed to multiple sites or posted to a listserv without the copyright holder's express written permission. However, users may print, download, or email articles for individual use. 